\title{
CULTURAL IDEOLOGY IN TRANSLATING SALATIGA LEGEND STORIES AND THEIR IMPLICATIONS IN TEACHING TRANSLATION
}

\author{
Tri Astuti \\ E-mail: triastuti2368@gmail.com
}

Received on Nov, $22^{\text {nd }}$, Revised on December, $4^{\text {th }}$, Published on December, $30^{\text {st }} 2019$

\begin{abstract}
The folklore of the Salatiga legend needs to be disseminated in the archipelago so that these cultural values can be understood by people from various ethnic groups in Indonesia using Indonesian. In the process of translating the legend (from Javanese Krama into Indonesian) it is necessary to have an appropriate translation method so that the message to be conveyed in the source language (BS) matches the target language (BT). This research aims to investigate the translation method used in the Salatiga Legend and explore the cultural ideology that affects the translator in translating the Salatiga Legend. In this research, only the translation of the word or phrase which is related to the translation is examined. This research is a descriptive qualitative research with content analysis method. Data processing techniques using literature study, see, and note. To test the validity of the data in the study used triangulation models, namely data triangulation, theory triangulation, and expert triangulation. The results of the research are the dominant translation methods used are equality and borrowing, while the transposition method is not found. The finding, translation methods used by translators in the Salatiga Legend story, especially those relating to the translation units of words and phrases of objects, are dominated by the equality method. In this study also no transposition method was found.
\end{abstract}

Keywords: Translation Method and Cultural Ideology

\begin{abstract}
ABSTRAK
Cerita rakyat legenda Salatiga perlu disebarluaskan di Nusantara sehingga nilai-nilai budaya ini dapat dipahami oleh orang-orang dari berbagai kelompok etnis di Indonesia yang menggunakan bahasa Indonesia. Dalam proses menerjemahkan legenda (dari bahasa Jawa ke bahasa Indonesia), perlu memiliki metode terjemahan yang sesuai sehingga pesan yang ingin disampaikan dalam bahasa sumber (BS) sesuai dengan bahasa target (BT). Penelitian ini bertujuan untuk menyelidiki metode penerjemahan yang digunakan dalam Legenda Salatiga dan mengeksplorasi ideologi budaya yang mempengaruhi penerjemah dalam menerjemahkan Legenda Salatiga. Dalam penelitian ini, hanya terjemahan kata atau frasa yang terkait dengan terjemahan yang diperiksa. Penelitian ini adalah penelitian kualitatif deskriptif dengan metode analisis isi. Teknik pengolahan data menggunakan studi literatur, melihat, dan mencatat. Untuk menguji validitas data dalam penelitian digunakan model triangulasi, yaitu triangulasi data, triangulasi teori, dan triangulasi ahli. Hasil dari penelitian ini adalah metode terjemahan dominan yang digunakan adalah kesetaraan dan pinjaman, sedangkan metode transposisi tidak ditemukan. Temuan, metode penerjemahan yang digunakan oleh penerjemah dalam kisah Legenda Salatiga, terutama yang berkaitan dengan unit terjemahan kata dan frasa objek, didominasi oleh metode kesetaraan. Dalam penelitian ini juga tidak ada metode transposisi yang ditemukan.
\end{abstract}

Kata kunci: Metode Terjemahan dan Ideologi Budaya 


\section{INTRODUCTION}

Translation is not something simple, it is not limited to translating from one language to another and it is not a job that anyone can do without learning. Translation has a strategic role in cultural development because it functions to divert messages that contain cultural elements from one language to another. Likewise, the translation of the Salatiga Legend story was translated from Javanese into Indonesian. Thus, the culture of a Javanese tribe will be known, understood, and adapted by other ethnic groups, even other nations that understand Indonesian. However, cultural messages have their own difficulties in translating because there are no two cultures in the same language. Nevertheless, the comparability of translation is very necessary for the arrival of messages from the source language (BS) to the target language (BT). These cultural differences cause the translator to be in a dilemmatic condition, namely the choice to maintain the source language (BS) or adapt it in the target language (BT). This is in accordance with the opinions (Saroukhil, Ghalkhani, \& Hashemi, 2018) translation is a reproduction of the closest natural equivalent, in terms of meaning and style, from the source language message into the target language. In both cases, equality plays a key role.

According to some experts, translation is always related to two conflicting things. First, translation in favor of the source language (BS) and second, translation in favor of the target language (BT). In the translation of fictional texts, such as legends, involves the culture of the source language (BS) because fiction texts are reflections of people's lives and contain connotative meaningful diction.

In choosing a translation method, a translator must first understand the object to be translated. In this research, the use of the translation method in the Salatiga legend will be examined. From the results of the study of these methods can be seen ideology related to translator culture. In order to be utilized in teaching, this research is associated with teaching translation.

In translation, a translator must pay attention to the role of culture in his translation. This is consistent with the opinion of Basssnett and Lafevere (Hatim \& Munday, 2004) who focus on interactions between translation and culture where culture influences and limits translation. There are three areas of cultural 
studies affecting translation, namely (1) translation as a rewrite which is the development of a theoretical system; (2) translation and gender; and (3) translation and postcolonialism. Furthermore, Lafevere focuses on concrete factors that systematically regulate reception, acceptance, or rejection of literary texts with issues of power, ideology, institutions, and manipulation.

Ideology is difficult to separate from culture. Culture is defined "... as the way of life and its manifestation," meaning ... as a way of life and its manifestations (Newmark, 1988). An important factor for translators is to make changes that reflect cultural biases that look acceptable and change source texts for ideological reasons that appear to have doctrine and are threatening. When translating and transferring a text to another culture with a different ideological origin, the target audience of the culture feels unfamiliar and the text is not good because of differences in the cultural principles of Bahasa Sumber (BS) and Bahasa Target (BT) beliefs.

Each text conveys a certain ideology and the original author's point of view when the writer expresses his opinion about the world, Heylen (in Delzendehrooy \& Karimnia, 2013) Translating ideology is not an easy translation, as is the opinion (Khosravi \& Branch, 2003) which says that it is difficult to conclude that there is a relationship between the ideology of the translator's religion and the translation of the Koran.

The ideological translation according to (Al-Mohannadi, 2008) depends on the translator who identifies the target audience and can change translations. If a translator knows the target audience, the translator may be tempted to change the original text, by adding or subtracting the original text so that it matches the reader's feelings. Therefore, translators should be filters to convince their readers. Translators not only use ideological values but strengthen the audience through the translator's translation.

Hatim and Mason consider ideological backgrounds to be better represented in language both at the lexical semantic level and grammatical syntactic level. Thus, the choice of words and the structure of the text of the writer and translator do not always feel guilty because behind the election there are objectives that explain the history, culture, and social politics. 
There are two types of ideologies, namely ideologies that are oriented to the source language and which are oriented to the target language. Therefore, Venuti in Amalia (2008) states that there are two ideologies, namely foreing and domesticating. Foreignizing translation is a translation that emphasizes the source language so that most use a kind of faithful and semantic translation. Domesticating translation is a translation that emphasizes the target language so that the translated text will refer to the culture of the target language community. The method used in domesticating translation uses adaptation, idiomatic and communicative translation.

This study uses the concept of procedures according to Jean-Paul Vinay and Darbelnet in (Chishiba, 2017) there are two approaches to translation, namely direct translation or literal and indirect translation (oblique translation). The direct translation approach includes three procedures, namely: (1) borrowing procedures, (2) calorie procedures, and (3) literal procedures. The indirect translation approach includes four procedures, namely: a) transposition procedures, b) modulation procedures, c) equality procedures, and d) adaptation procedures.
Translation research in international journals has been carried out by researchers, including an article entitled Back-Translation Technique to Assess the Students' Translation of Literary Text (Kharis \& Afifah, 2017) Das Brot's translation has produced translations equivalent to ST. Only a few show uneven realization in form and meaning. This shows that students have been relatively successful in the translation process. Differences are also identified in meaning or in form, and in both. The uneven translation is largely the result of improper lexicon selection, which results in meaningful differences. In addition, various forms of sentences adversely affect the translation. Some transpositions in the translation have changed the original message.

Furthermore (Delzendehrooy \& Karimnia, 2013), an analysis of modulation in English translations of Khayyam's strong words carried out by Fitzgerald and Emami revealed that translators had changed the point of view and semantics of the original work almost to the same degree. More than implementing a chi-square procedure shows that the variable frequency is different for each translation separately. Meanwhile, the same for both translations as a whole. In 
short, this research, which is comparative in nature, might explain the translation process because part of it is comparative language style. This can also be useful for students because it helps them identify characteristics that distinguish their mother tongue from foreign languages (in our English and Persian) so as to see the phenomenon that each language has a certain wealth and people in different languages express situations differently because their minds and forms are different. In addition, statistical data showing various points of view of different languages will be very attractive to linguists and translators. Furthermore, (Nefedova \& Polyakov, 2015) in his article discusses the problem of lending about expressions set from English to German and Russian, whose degree of system varies, different from the first. Analysis of the function of news expression borrowed from English in Germany and the online political magazine Spiegel and Russian socio-political newspaper Kommersant in 2004 to 2014 have revealed direct and heat loans. Most expressions borrowed from English together are new loan concepts and phenomena. Most of those who borrowed from English to Germany over the last few decades are direct loans (around 70\%). Although direct loans come with heat, the former is used more often. Translations in the form of loans to modern German lose their relevance, while expressions held by Russia are still very good.

\section{RESEARCH METHODOLOGY}

This research is a qualitative descriptive study. The source of the research data is the story of the Salatiga Legend in Javanese and Indonesian taken from internet sources. This research uses content analysis method, literature study, refer to, and note. The data processing technique is carried out by observing the translation method used by the translator from Javanese (BS) into Indonesian (BT), especially with regard to the translation units of words and noun phrases. To test the validity of the data triangulation models are used, namely data triangulation, theory triangulation and expert triangulation.

The procedure in this study is as follows. First, reading the two Salatiga Legend texts, namely Javanese text as the source language (BS) with Indonesian text as the target language (BT), Second, listing words or phrases of objects from Javanese (BS) and Indonesian (BT) . Third, analyze the words or phrases of the two languages and enter them according to seven methods of translation in accordance with the theory. 
Fourth, observe the ideological tendencies of translator culture based on the results of the analysis of the method of translating words or noun phrases. Fifth, it implies in teaching translation. Sixth, conclude and present it in research.

\section{RESULTS AND DISCUSSION}

\section{Translation Procedure in the Prambanan Temple Legend}

The direct translation approach in this study includes three procedures, namely: the borrowing procedure, the calque procedure, and the literal procedure. The indirect translation approach includes four procedures, namely: transposition procedures, modulation procedures, equality procedures, and adaptation procedures (Jean-Paul Vinay and Darbelnet in Emzir, 2013: 64-73) .

The direct and indirect translation approaches were analyzed in the text of the Salatiga Legend story to determine the dominance of the use of procedures in translating the text, especially those related to words or phrases of objects.

\section{Borrowing}

Borrowing is the simplest of all the translation methods. This method is useful if the translator wants to introduce the cultural sense of the source language (BS) into his translation, foreign terms can be used.

For example:

Sunan Kalijaga (Java) - Sunan Kalijaga (Indonesia) Emas (Java) - Emas (Indonesia) wali (Java) - wali (Indonesia)

\section{Calque}

Calque is a special type of loan in which a language borrows other forms of expression, but then literally translates each of its elements. Calque is divided into two types, namely (1) lexical calque is a calque that respects the syntactic structure of BT, while a new mode of expression and (2) structural calque is a calque that introduces a new construction in language.

For example:

telung error (Java) - three errors (Indonesia) Pandanarang (Java) - Pandanarang II (Indonesia)

\section{Literal Translation}

Literal or word-for-word translation is the direct transfer of a BS text into a BT text which is grammatically and idiomatically appropriate. The task of translators is limited to observing adherence to BT linguistic services. In principle, literal translation is a reversible and complete unique solution in itself. This is 
most common when translating between two cognate languages.

For example:

Pandanarang lajeng sad and sad wangsulan punika (Java) - And Ki Ageng was angry with the old man (Indonesia).

Legend rarely found literary translation. Translators often add a few words or sentences or even reduce them so that the story seems to have shifted, but basically the essence is the same.

\section{Transposition}

Transposition is a method that involves replacing one class of words with another without changing the meaning and message. In addition to being a special translation, transposition procedures can also be applied in a language. There are two kinds of transpositions in translation, namely: (1) compulsory transposition and (2) optional transposition. In this study no transposition translation procedure was found. This is due to the use of transposition used by translators to divert messages from the source language (BS) to the target language (BT). Thus, the lack of transposition in the translation of the Salatiga Legend shows that the translator did not aim to divert certain messages from Javanese (BS) into Indonesian (BT). This is in accordance with the opinions (Kharis \&
Afifah, 2017) some transpositions in translation can change the original message.

\section{Modulation (modulation)}

Modulation is a variation of the form of messages obtained by changing the point of view. This change can be justified when, even if literal or even diverted, is the result of translation in the correct grammatical utterance deemed inappropriate, not idiomatic, or awkward in

For example:

wong wadon tuo (Java) - woman (Indonesia) Nyai Pandanarang (Java) - wife of Ki Ageng Pandanaran (Indonesia)

The word wong wadon tuo should be interpreted as an old woman and the word Nyai Pandanarang means a woman who is elder and honorable, but translated as a wife who has a neutral sense of value.

6. Equality (equivalence)

Most of the equivalents are fixed and belong to the repertoire associated with the preparation of idioms, cliches, proverbs, nominal phrases or adjectives, etc.

For example:

duke (Java) - regent (Indonesia)

wadon (Java) - woman (Indonesia)

teken (Javanese) - stick (Indonesian)

pring (Java) - bambu (Indonesia) 
Adaptation is an extreme method of translation because it is used in cases where the type of situation mentioned in the BS message is unknown to BT culture. Translators must create new situations that can be considered equal. Therefore, adaptation can be described as a special type of equality, that is situational equality.

For example: gangsal sen (Java) - a piece of money (Indonesia)

A penny wedge should be interpreted as five cents. The translator chose the word piece of money because the penny is now unknown in Indonesia. Sen was known in ancient times so that it can be said to be due to the influence of certain situations so that translators translate the word piece of money so that it is easily understood. From the results of the study it can be said that in translating the Salatiga Legend from Javanese into Indonesian, translators use the equality and borrowing translation method more than others. In addition, this study did not find a transposition translation method.

\section{Cultural Ideology in Translating Salatiga Legend Stories}

In this study found the ideology of source language culture (BS) that affects the translation of the Salatiga Legend.
Translators prefer translation of foreignizing translations, that is, translations that emphasize the source language so that most use a type of faithful and semantic translation. This can be proven from the results of the analysis that the translator uses the equality and borrowing methods which are more dominant and no other ideology is found in the translation method, especially those related to nouns and phrases. The translation of legendary stories that are part of cultural translation in the cognate language community tends not to bring up different ideologies. Javanese and Indonesian languages have the same language family, namely the Austronesian family, so that the translation of the Salatiga Legend from Javanese (BS) into Indonesian (BT) does not lead to a different ideology because it is still in the context of a language and culture that is almost the same. If we observe, in the vocabulary of Indonesian many of them take from the repertoire of regional languages, including Javanese.

Even so, this research also found nouns that were not found in Javanese (BS), but were found in Indonesian translations (BT), namely the word tasbih. The translator intentionally added the word in 
the depiction of the figure of Sunan Kalijaga. The addition of these words is an intentional translator to warm the thick Islamic culture to the figure of Sunan Kalijaga. However, the addition of the word was not as a dominant element and changed a cultural view of the Javanese language community (BS) because even in the view of the Javanese cultural community it was well known that Sunan Kalijaga was one of the saints who always prayed and carried prayer beads.

Implications of Cultural Ideology in Translating Salatiga Legend Stories in Teaching Translation in the Classroom

In teaching translation, such as the Salatiga Legend Story, a teacher is required to first understand the object to be translated. Different objects or texts have different characteristics in translation. Translating literary texts is clearly different from legal or computer translations. After understanding the object or text to be translated, a teacher must also understand the methods used in translation. Using the wrong translation method will affect the results of the translation. Furthermore, a teacher must be able to relate it to the ideology of the source language (BS) culture with the target language (BT). According to (Xian, 2008), researchers and translators must recognize the linguistic and cultural differences that must be negotiated by translating data. It is said here that researchers and translators must preserve and highlight cultural differences rather than resemble the dominant values of the target culture with translation. A translator is an integral part of the knowledgeproducing system. The role of translators as intercultural communicators and data translators must be recognized in the research process.

In order for the teaching of translation in the classroom to be attractive to students, a teacher must be able to implement appropriate teaching strategies and in accordance with the conditions of the students. According to (Awal, HoAbdullah, \& Zainudin, 2014), some of the translation class research findings show mixed responses to cooperative learning. In general, most students prefer group work, but a large number of respondents stated that they prefer to work alone. That suggests that they prefer groups smaller than 2 to 3 members compared to groups of 4 to 5 members. This finding clearly shows that respondents can be categorized as competitive students, who are more individualistic than cooperative students. This finding also shows that the majority of respondents liked to discuss their 
translation work with their classmates even though they did not like the idea of working in groups. This is a positive sign that the discussion is beneficial for the translation class. Respondents were also positive about the ability to exchange ideas in groups and they found translation to be easier when done in group work.

\section{CONCLUSIONS}

From the results of the study it can be concluded that the translation methods used by translators in the Salatiga Legend story, especially those relating to the translation units of words and phrases of objects, are dominated by the equality method. In this study also no transposition method was found. The ideology of translation used in this legendary story is foreignizing translation, which is a translation that emphasizes the source language so that most use the type of faithful and semantic translation. This is because Javanese and Indonesian languages are the same language family, the Austronesian language family. In the same language family, most of the same language and culture are found. Thus, in the translation method of the Salatiga Legend story, especially those relating to words and phrases of objects, translators use the equality and borrowing methods more so that the results of the translation, related to the words or phrases of objects, are still closely related and easily understood by both language cultures and thus cause there is a match between the two languages.

\section{REFERENCE}

Al-Mohannadi, S. (2008). Translation and ideology. Social Semiotics, 18(4), $529-542$.

https://doi.org/10.1080/103503308024 89050

Amalia, F. (2007) Ideologi dalam Penerjemahan. Direktori File UPI

Awal, N. M., Ho-Abdullah, I., \& Zainudin, I. S. (2014). Parallel Corpus as a Tool in Teaching Translation: Translating English Phrasal Verbs into Malay. Procedia - Social and Behavioral Sciences, 112(Iceepsy 2013), 882-887. https://doi.org/10.1016/j.sbspro.2014.0 1.1245

Chishiba, G. (2017). An Analysis of the Translation Strategies Used to Translate, from English into Nyanja, Zambia's "A Simple Guide to the Anti Gender Based Violence (GBV) Act." International Journal of Applied Linguistics and Translation, 3(1), 10. https://doi.org/10.11648/j.ijalt.201703 01.12

Delzendehrooy, M., \& Karimnia, A. (2013). 
A comparative study of modulation in English translations of Khayyam's Quatrains. Procedia- Social and Behavioral Sciences, 70, 28-40. https://doi.org/10.1016/j.sbspro.2013.0 1.035

Emzir.(2015). Teori dan Pengajaran

Penerjemahan. Depok: Rajagrafindo Persada.

Hatim, B., \& Munday, J. (2004). Transaltion: An advanced resource book.

Kharis, M., \& Afifah, L. (2017). BackTranslation Technique to Assess the Students ' Translation of Literary Text, $\quad 5(1), \quad 25-28$. https://doi.org/10.11648/j.ij1l.2017050 1.14

Khosravi, H., \& Branch, R. (2003). Influence of Translator's Religious Ideology on Translation: A Case Study of English Translations of the Nobel Quran, 151-163.

https://doi.org/10.1109/ROBOT.2007. 363925

Nefedova, L. A., \& Polyakov, O. G. (2015).

Set Expressions Borrowed from English into German and Russian: Direct Loans or Calques? Procedia Social and Behavioral Sciences, 200(October), 83-86. 6/j.sbspro.2015.08.020

Newmark, P. (1988). A Text Book of Translation. New York and London: Prentice-Hall.

Saroukhil, M. A., Ghalkhani, O., \& Hashemi, A. (2018). A Critical Review of Translation: A Look Forward, (c).

Xian, H. (2008). Lost in translation? Language, culture and the roles of translator in $\quad$ cross $\square$ cultural management research. Qualitative Research in Organizations and Management: An International Journal, 3(3), 231-245. https://doi.org/10.1108/174656408109 20304

https://doi.org/http://dx.doi.org/10.101 